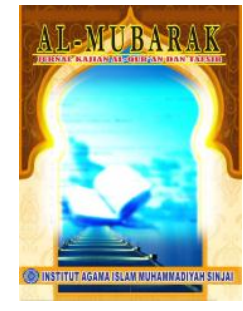

\title{
WAWASAN AL-QUR'AN TENTANG LAKNAT
}

\author{
Hawirah \\ ${ }^{1}$ Institut Agama Islam Muhammadiyah Sinjai \\ E-mail: hawirahh@gmail.com,Tlp: +6285299951322
}

\begin{abstract}
Abstrak
Tujuan penelitian ini adalah untuk mengungkap laknat perspektif al-Qur`an. Metode kajian yang digunakan dalam penelitian ini adalah metode kajian tematik dengan menetapkan laknat sebagai tema. Pengumpulan datanya dilakukan dengan menelusuri ayat-ayat yang laknat dalam al-Qur`an. Guna melengkapi data dan hasil yang valid, dikemukakan juga penjelasan mufassir terkait laknat. Akhirnya, penelitian ini memberikan sebuah informasi baru bahwa kata laknat dengan berbagai bentuk derivasinya ditemukan dalam 40 ayat al-Qur`an. Kesimpulan yang dapat diambil di antaranya: 1) Laknat dalam al-Qur'an adalah dijauhkan dan diusir dari rahmat Allah disertai dengan murka-Nya di dunia dan hukuman neraka di akhirat kelak. 2) Di antara objek laknat adalah Iblis, Bani Israil, orang kafir, orang munafik, pendusta, serta penguasa yang lalim. 3) Penyebab terjadinya laknat adalah ingkar kepada Allah dan Rasul-Nya, sengaja menyembunyikan ilmu, memutuskan silaturrahim, membunuh orang mukmin dengan sengaja, menuduh wanita baik-baik berbuat zina, dan membuat kerusakan di muka bumi dalam bentuk apa pun. 4) Cara menghindari laknat Allah adalah dengan beriman dan bertakwa, berlomba-lomba dalam kebajikan, serta selalu menyucikan hati dan pikiran.
\end{abstract}

Kata Kunci: Wawasan al-Qur'an, Laknat, Tematik

\section{Pendahuluan}

Dalam hidup ini seringkali sulit membedakan antara nikmat ataukah laknat. Karena tidak semua hal baik yang datang pada kita itu berupa nikmat, bisa saja yang datang justru berupa laknat. Banyak sekali kita mengucapkan syukur terhadap apa yang telah terjadi padahal belum tentu itu adalah sebuah nikmat yang dianugerahkan kepada kita melainkan sebuah laknat yang dibungkus dengan kebaikan. Misalnya saja dalam kehidupan kita ada sebagian orang yang hidup berkecukupan dengan harta yang diperoleh dengan cara yang sah dan wajar, baik dengan cara bekerja sebagai karyawan/pegawai, berwira usaha hingga menjual jasa lewat beragam profesi. Orang-orang ini, akan selalu merasakan kemahahadiran Tuhan dalam semua tahapan proses mencari, mendapatkan dan menggunakan harta yang diperoleh. Karena semua tahapan proses yang dilalui, diyakini tidak melanggar aturan Tuhan maupun aturan manusia. 


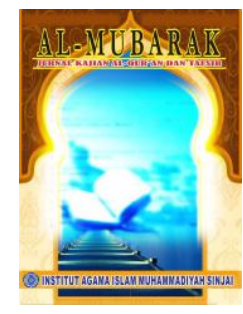

\section{Al-MUBARAK}

Jurmall Kajian Al-Quran \& Tafsir

Volume 4, No. 2, 2019

P-ISSN: 2548-7248

E-ISSN: 2715-5692

Homepage : http://journal.iaimsinjai.ac.id/indeks.php/al-mubarak

Dalam Islam terdapat suatu kondisi di mana kenikmatan hidup bisa berubah menjadi laknat dan karunia yang diberikan kepada manusia merupakan laknat Allah, hal ini disebut dengan istidraj, yakni pemberian Allah kepada orang yang sering melakukan maksiat kepadaNya. Semakin mereka melupakan Allah, Allah akan menambahkan kesenangan bagi mereka.

Kata laknat sendiri dalam bahasan al-Qur`an secara garis besar sama dengan musibah, azab, fitnah, nikmat atau bala`. Para mufasir pun berbeda-beda dalam menafsirkannya. Namun jika dikaitkan dengan fenomena alam atau kejadiankejadian yang menimpa manusia secara umum, kepastian tentang laknat atau musibah atau azab atau bala atau fitnah masih belum dapat dipastikan. Yakni suatu musibah atau azab yang dirasakan oleh seseorang atau suatu kaum apakah dapat dikategorikan laknat atau bukan (Ismail Amir, 2011: 3).

Berangkat dari fenomena di atas, menarik kiranya untuk diuraikan lebih lanjut mengenai wawasan al-Qur`an tentang laknat.

\section{Metode}

Penelitian ini adalah penelitian kualitatif. Penelitian ini juga tergabung dalam penelitian tafsir yang menggunakan metode penelitian tafsir tematik. Secara operasional, prosedur tafsir tematik dapat dilihat secara singkat pada uraian ini. Pertama, membahas ayat-ayat Al-Qur`an sesuai dengan tema atau judul yang telah ditetapkan. Dalam hal ini judul yang ditetapkan adalah laknat dalam perspektif al-Qur'an. Kedua, semua ayat yang berkaitan dengan topik tersebut dihimpun. Kemudian dikaji secara mendalam dan tuntas dari segala aspeknya seperti asbab al-nuzul, kosa kata, istinbath hukum, dan lain-lain. Semua itu dijelaskan secara rinci dan tuntas, serta didukung oleh dalil-dalil dan fakta (jika ada) yang dapat dipertanggungjawabkan secara ilmiah baik argumen itu dari AlQur`an dan hadis, maupun pemikiran rasional. Ketiga, mengumpulkan interpretasi para ulama tafsir lalu menganalisanya dan berusaha memberikan sebuah kesimpulan. 


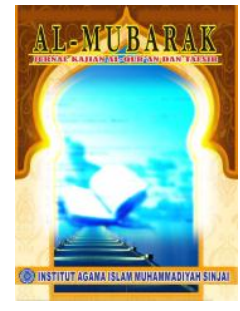

AI-MUBARAK

Jurmall Kajian Al-Quran \& Tafsir

Volume 4, No. 2, 2019

P-ISSN: 2548-7248

E-ISSN: 2715-5692

Homepage : http://journal.iaimsinjai.ac.id/indeks.php/al-mubarak

\section{Pembahasan}

\subsection{Pengertian Laknat}

Secara bahasa kata la'ana bermakna terhina karena terkutuk, Sedangkan kata al-la'nu yaitu jauh dan tersingkir dari kebaikan, atau tersingkir dan jauh dari Allah. Sedangkan laknat dari manusia yaitu mendoakan (Ibnu Manzhur, t.th.: 504).

Menurut Muhammad Mutawalli Sya'rawi (w. 1998 M) yang dimaksud kata la'ana (dilaknat) yakni dijauhkan dari rahmat Allah. Ketika laknat itu dinisbatkan kepada Allah yang maha kuasa maka laknat itu sangat dahsyat, karena sesuatu perbuatan itu sesuai dengan kekuatan siapa yang melakukannya. Misalnya ketika anak kecil melempar batu ke depannya, maka lemparan sesuai dengaan usia dan kekuatannya. Namun bila orang yang lebih besar melempar batu, maka semakin besar batunya dan semakin jauh pula jangkauannya. Apabila yang melaknat Allah adalah Allah maka disini tidak ada standar kekuatan laknat yang dapat diketahui oleh akal manusia (Mutawalli Sya'rawi, 2004: 338). Sedangkan menurut Ahmad Mustafa al-Maraghi (w. 1371 H) kata العنة - al-la’nah: (laknat), artinya dijauhkan atau diusir (al-Marâghi, 1992: 54).

Dari pengertian di atas dapat disimpulkan bahwa laknat berarti ia dijauhkan dan diusir dari rahmat-Nya disertai dengan murka Allah di dunia dan hukuman neraka di akhirat kelak. Sebagaimana Firman Allah:

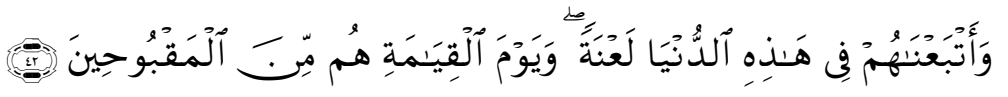

Terjemahnya:

"Dan Kami susulkan laknat kepada mereka di dunia ini, sedangkan pada hari Kiamat mereka termasuk orang-orang yang dijauhkan (dari rahmat Allah)" (Depag RI, 2008: 390).

\subsection{Laknat dalam al-Qur`an}

Kata la'ana (laknat) dalam berbagai bentuk derivasinya terungkap di dalam al-Qur’an sebanyak 41 kali dalam 40 ayat dan dalam 18 surat (Muhammad Fuad abd al-Bâqî, 2007: 748-749).

Kata laknat dalam al-Qur`an terdapat dalam beberapa bentuk yaitu: (1) Dalam bentuk fi'il madhi mabni ma'lum disebutkan sebanyak 6 kali dalam bentuk 


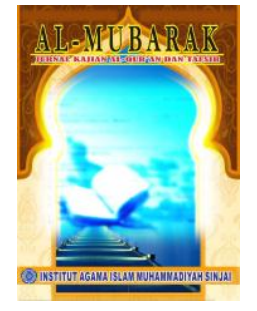

\section{Al-MUBARAK}

Jurnall Kajian Al-Quran \& Tafsir

Volume 4, No. 2, 2019

P-ISSN: 2548-7248

E-ISSN: 2715-5692

Homepage : http://journal.iaimsinjai.ac.id/indeks.php/al-mubarak

yang berbeda, yaitu kata (2) Dalam bentuk fíl madhi mabni majhul disebutkan sebanyak 2 kali dalam bentuk yang berbeda,

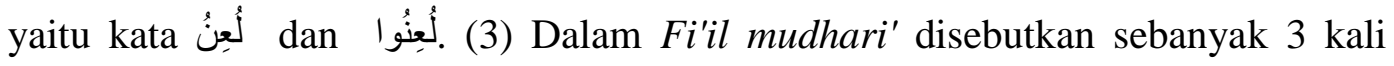

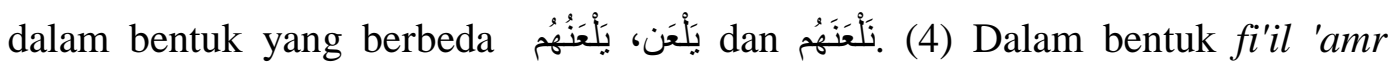
disebutkan hanya 1 kali, yakni kata إلْعَنْهُ لِعُن (5) Dalam bentuk masdar disebutkan

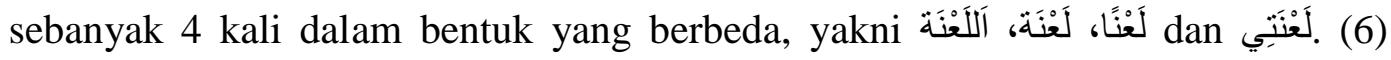
Dalam bentuk isim fấil yakni kata آَلَّلَعُْونَن (7) Dalam bentuk isim maf'ul, yakni

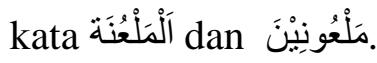

Ungkapan yal'anuhumullah (Allah melaknat mereka) mengandung pengertian bahwa Dia mengusir dan menjauhkan mereka dari rahmat-Nya. Sebagai contoh, kata yal'anu (بَلْعَنُ) yang merupakan bentuk fi'il mudhari', terdapat dalam firman Allah:

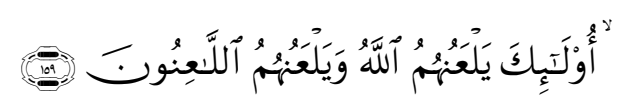

Terjemahnya:

"Mereka itulah yang dilaknat Allah dan dilaknat (pula) oleh mereka yang melaknat" (Depag RI, 2008: 24).

Asal kata yal'anu (بَلْعَنُ) adalah al-la'n (الََعْن) artinya “mengusir dan menjauhkan sesuatu atau seseorang akibat perbuatan yang menimbulkan kemurkaan. Orang yang mendapat laknat Allah berarti ia dijauhkan dari rahmatNya disertai dengan kemurkaan Allah di dunia dan hukuman neraka di akhirat kelak. Laknat Allah dalam ayat ini berarti terputusnya rahmat dan taufik Allah disertai kemarahan Allah atas orang-orang yang menyembunyikan hidayah alQur`an ketika mereka membaca kitab Taurat, sedangkan laknat Allah di akhirat adalah azab neraka (Kemenag RI, 2010: 236).

Kata al-Lâ'inûn-النَّنُنْن- (yang melaknat), yaitu para malaikat dan orangorang mu'min. Maksudnya adalah laknat yang sifatnya terus-menerus (Salman Nashif Ad-Dahduh, $2008: 8$ ).

Kata la'anahu - لَعَنَهُ- (ia melaknatnya) sebagai fi'il, yakni mengusir dan menjauhkannya diiringi dengan perasaan marah. Sebagaimana firman Allah:

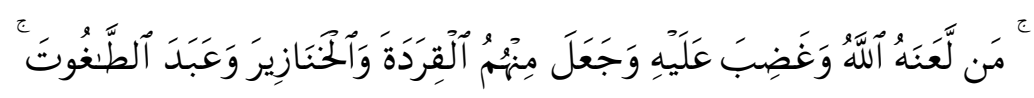




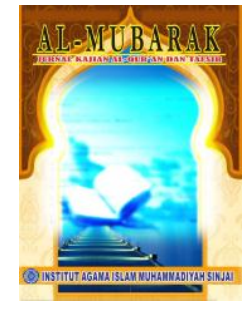

AI-MUBARAK

Jurmall Kajian Al-Quran \& Tafsir

Volume 4, No. 2, 2019

P-ISSN: 2548-7248

E-ISSN: 2715-5692

Homepage : http://journal.iaimsinjai.ac.id/indeks.php/al-mubarak

Terjemahnya:

" Yaitu, orang yang dilaknat dan dimurkai Allah, di antara mereka (ada) yang dijadikan kera dan babi dan (orang yang) menyembah thaghut?". Mereka itu lebih buruk tempatnya dan lebih tersesat dari jalan yang lurus" (Depag RI, 2008: 118).

Kata al-la'nah -اللعنة- dalam firman Allah:

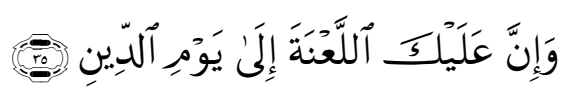

Terjemahnya:

"Dan sesungguhnya kutukan itu tetap menimpamu sampai hari kiamat" (Depag RI, 2008: 264).

Adapun pada surah al-Hijr, terlihat bahwa uraian tentang persoalan ini menggunakan kata-kata yang diawali dengan huruf alif dan lâm (al), seperti alsâjidîn, al-insân, al-jân. Dengan demikian, sangat wajar pula jika kata laknat dihiasi pula dengan kedua huruf tersebut sehingga berbunyi (اللعنة) al-la'nah dan bukan (لعنتي) la'natî.

Bahwa ayat ini (QS. al-Hijr/15: 35) mengarahkan jatuhnya laknat kepada iblis karena setiap kedurhakaan mengundang laknat, sedang tidak satu kedurhakaan pun yang tidak melibatkan iblis melalui rayuan dan godaannya. Dengan demikian, setiap kedurhakaan yang dilakukan seseorang, dampak buruknya di samping akan menyentuh pelakunya sendiri, juga akan menyentuh pendorongnya (iblis). Dengan demikian, bertumpuk laknat atas iblis sampai hari Kemudian karena kedurhakaan akan terus-menerus terjadi hingga hari kemudian (M. Quraish Shihab, 2009: 459).

Dan kata al-la'în sebagai maf'ul berarti yang dilaknat, yaitu predikat yang diberikan kepada iblis (setan) karena dia telah terusir dari langit dan dijauhkan dari rahmat Allah swt. (Majdi as-Sayyid Ibrahim, 1995 : 11).

\subsection{Objek Laknat}

\section{a. Iblis}

Banyak pakar bahasa berpendapat bahwa kata iblîs terambil dari bahasa Arab ablasa yang berarti putus asa atau dari kata balasa yang berarti tiada kebaikan. Ada juga yang berpendapat bahwa kata iblîs berasal bahasa Yunani, yakni Diabolos. Kata ini terdiri dari kata dia yang berarti di tengah atau sewaktu dan ballein yang berarti melontar atau mencampakkan. Dari penggabungannya, 


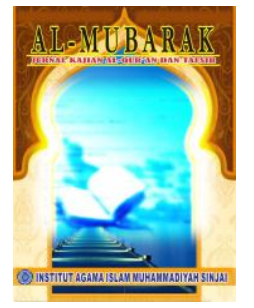

\section{AI-MUBARAK}

Jurnall Kajian Al-Quran \& Tafsir

Volume 4, No. 2, 2019

P-ISSN: 2548-7248

E-ISSN: 2715-5692

Homepage : http://journal.iaimsinjai.ac.id/indeks.php/al-mubarak

lahir beberapa makna antara lain menentang, menghalangi, dan yang berada antara dua pihak untuk memecah belah dan menciptakan kesalahpahaman. Namun pendapat ini tidak sepenuhnya didukung oleh banyak ulama, walau makna-makna itu tidak meleset dari ulah iblis dan setan (M. Quraish Shihab, 2009: 457). Dengan kata lain, iblis adalah induk segala makhluk yang diciptakan dari api dan berperilaku setan.

Kedurhakaan iblis kepada Allah sampai menerima laknat-Nya, terbukti dalam firman Allah:

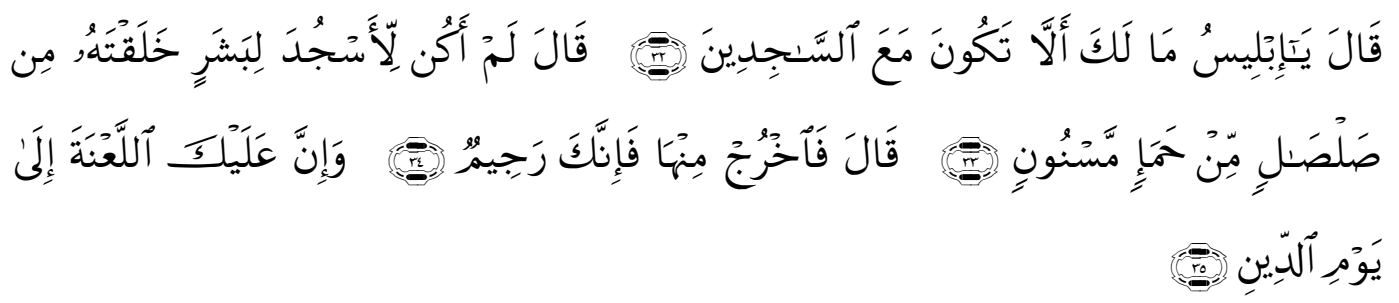

Terjemahnya:

"Dia (Allah) berfirman: "Wahai iblis! Apa sebabnya kamu (tidak ikut) sujud bersama?" Ia (Iblis) berkata: "Aku sekali-kali tidak akan sujud kepada manusia yang Engkau telah menciptakannya dari tanah liat kering dari lumpur hitam yang diberi bentuk" Dia (Allah) berfirman: "(kalau begitu) keluarlah dari surga, karena sesungguhnya kamu terkutuk, dan sesungguhnya kutukan itu tetap menimpamu sampai hari kiamat" (Depag RI, 2008: 264).

Iblis menolak sujud bukan dengan alasan bahwa sujud kepada Âdam as. adalah syirik, seperti dugaan sebagian orang. Keengganannya bersumber dari keangkuhan yang menjadikan ia menduga dirinya lebih baik dari Âdam akibat dari faktor yang melekat pada diri iblis yakni keangkuhan dan kedengkian, yang ia jelaskan sendiri di ayat lain dengan ucapannya:

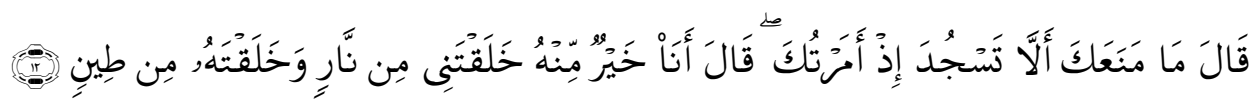

Terjemahnya:

"(Allah) berfirman: "Apakah yang menghalangimu (sehingga) kamu tidak bersujud (kepada Adam) ketika Aku menyuruhmu?" (Iblis) menjawab "aku lebih baik daripada dia, Engkau ciptakan aku dari api sedangkan dia Engkau ciptakan dari tanah" (Depag RI, 2008: 152).

Jawaban iblis, dalam ayat di atas, menunjukkan bahwa ia benar-benar memiliki sifat angkuh, bukan saja terhadap Âdam as., tetapi juga terhadap perintah Allah. Iblis merasa bahwa perintah Allah baru pantas diikuti kalau sesuai 


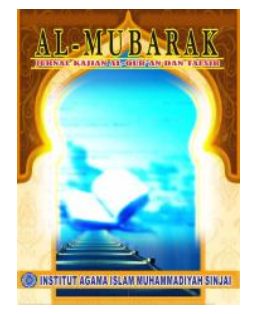

Al-MUBARAK

Jurnall Kajian Al-Quran \& Tafsir

Volume 4, No. 2, 2019

P-ISSN: 2548-7248

E-ISSN: 2715-5692

Homepage : http://journal.iaimsinjai.ac.id/indeks.php/al-mubarak

dengan pikirannya, padahal pikiran makhluk sangat terbatas. Karena keterbatasan itulah maka ia menduka bahwa kemuliaan bersumber dari asal kejadian, bukan sifat-sifat yang disandang. Allah menjawab keangkuhan iblis itu "Keluarlah dari surga, karena Sesungguhnya kamu terkutuk, sedang siapa yang terkutuk tidak wajar menerima rahmat apalagi syurga, dan sesungguhnya atas mereka secara khusus laknat, yakni dijauhkan dari rahmat Allah, yang berlanjut pada terus sampai Hari kiamat dan setelah kiamat datang kutukan itu akan disertai dengan siksa yang pedih. (M. Quraish Shihab, 2009: 169-170).

Iblis patut mendapat laknat Allah sampai di akhirat kelak karena sifat keangkuhan yang menjadikan ia menduga dirinya lebih baik dari Âdam akibat dari faktor yang melekat pada diri iblis yakni keangkuhan dan kedengkian, dan karena dia telah berjanji untuk menyesatkan anak Âdam. Laknat di dunia bagi iblis adalah dijauhkannya dari segala kebaikan dan diusirnya mereka dari syurga untuk selama-lamanya, dan di akhirat kelak mereka kekal dalam neraka jahannam.

\section{b. Bani Israil}

Al-Qur`an al-karim telah membahas Bani Israil dengan jelas dan transparan, terutama di dalam surat al-baqarah. Bahkan pembicaraan tentang diri mereka hampir memenuhi satu juz tersendiri. Hal ini menunjukkan perhatian yang besar terhadap berbagai hakikat orang-orang Yahudi, untuk membuka keburukan dan kejahatan yang bersarang di dalam jiwa mereka, seperti tipu daya, makar, kebobrokan dan kerusakan, agar kaum muslimin berhati-hati terhadap mereka (Muhammad Ali ash-Shabuni, 2000: 15).

Bani Israil yang selalu menyikapi karunia, nikmat, kemurahan dan kebaikan dari Allah dengan pengingkaran dan pembangkangan, ejekan dan olok-olok terhadap ayat-ayat Allah, menumpahkan darah dan membunuh para nabi. Karena itulah kehinaan dan kenistaan selalu menyertai mereka, disamping mereka layak mendapat laknat dari Allah, sebagaimana firman Allah:

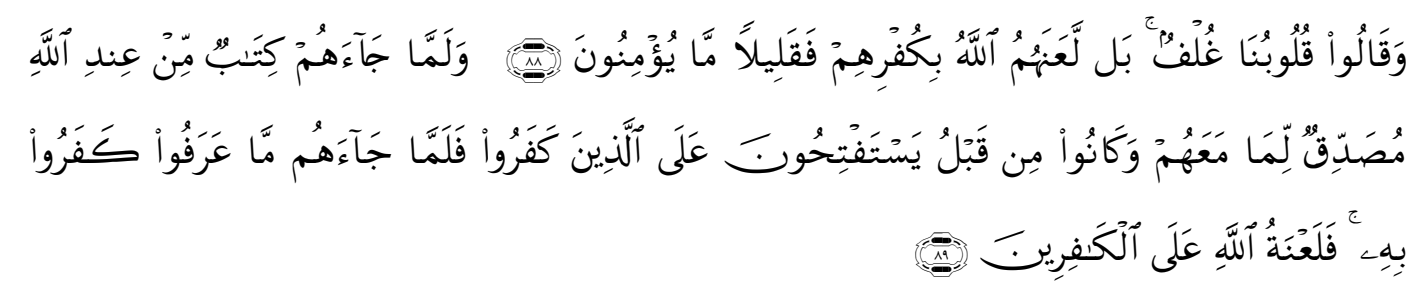




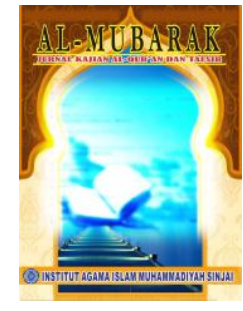

Al-MUBARAK

Jurmall Kajian Al-Quran \& Tafsir

Volume 4, No. 2, 2019

P-ISSN: 2548-7248

E-ISSN: 2715-5692

Homepage : http://journal.iaimsinjai.ac.id/indeks.php/al-mubarak

Terjemahnya:

"Dan mereka berkata:"Hati kami tertutup". Tidak! Allah telah melaknat mereka itu karena keingkaran mereka, tetapi sedikit sekali mereka yang beriman. "Dan setelah kepada mereka Kitab (Al-Qur'an) dari Allah yang membenarkan apa yang ada pada mereka, sedangkan sebelumnya mereka memohon kemenangan atas orang-orang kafir, ternyata setelah sampai kepada mereka apa yang telah mereka ketahui itu, mereka mengingkarinya. Maka laknat Allah bagi orang-orang yang ingkar" (Depag, 2008: 13-14).

Dahulu kaum Yahudi tinggal di Madinah, bersama mereka hidup pula kaum

Aus dan Khazraj yang keduanya musyrik. Ketika terjadi perseteruan diantara mereka, kaum Yahudi mengancam mereka dengan kedatangan seorang rasul. Ketika rasul saw. datang, mereka malah mengingkarinya dan mengingkari apa yang diturunkan kepadanya yaitu al-Qur`an (Mutawalli Sya'rawi, 2004: 340).

Kekafiran mereka (Bani Israil) amat buruk karena mereka mengingkari nabi yang mereka nanti-nantikan sendiri, dan mereka memohon kedatangannya untuk mendapat kemenangan di dalam menghadapi musuh-musuh mereka. Padahal, rasul itu telah datang kepada mereka dengan membawa kitab yang membenarkan apa yang ada pada mereka (Kitab Taurat). Itulah tindakan mereka yang patut mendapatkan pengusiran dan kemurkaan karena kejelekkan dan keburukannya. Oleh karena itu, ditimpakanlah kepada mereka laknat dan dijadikannya mereka tuli karena kekafirannya (Sayyid Quthb, 1992: 110). Sebagaimana dalam firman Allah:

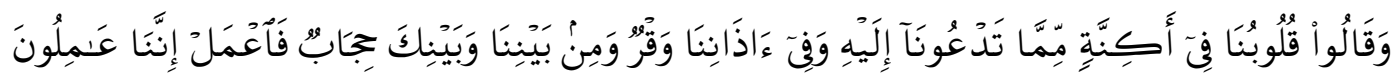

Terjemahnya:

"Dan mereka berkata: "Hati kami sudah tertutup dari apa yang engkau seru kami kepadanya dan telinga kami tersumbat, dan di antara kami dan engkau ada dinding, karena itu lakukanlah (sesuai kehendakmu), sesungghnya kami akan melakukan (sesuai kehendak kami)" (Depag, 2008: 477).

Allah swt. menerangkan, bahwa setelah al-Qur`an datang dari sisi Allah, orang-orang Yahudi dan Nasrani mengingkarinya, padahal Al-Qur’an memberi petunjuk serta membenarkan Kitab Taurat yang ada pada mereka, yang sebelumnya sangat mereka harapkan kedatangannya untuk membenarkan apa yang terdapat dalam kitab mereka. Tetapi setelah kebenaran yang mereka ketahui datang, mereka tidak mau beriman. Sebabnya ialah karena mereka merasa akan kehilangan pengaruh, kekuasaan dan harta benda. Maka patutlah Allah melaknat 


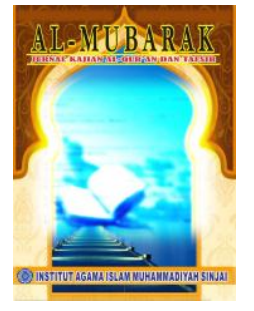

Al-MUBARAK

Jurnall Kajian Al-Quran \& Tafsir

Volume 4, No. 2, 2019

P-ISSN: 2548-7248

E-ISSN: 2715-5692

Homepage : http://journal.iaimsinjai.ac.id/indeks.php/al-mubarak

mereka, sebagai imbalan kekafiran yang bersarang dalam dada mereka (Kemenag, 2010: 149).

Diriwayatkan oleh Ibnu Jarir dari Qatadah al-Anshari dari orang-orang tua dari kalangan Anshar mereka berkata, "kisah yang tersebut dalam ayat ini adalah mengenai kami dan orang-orang Yahudi Madinah. Kami dahulu pernah menjalankan agama mereka pada masa Jahiliyyah, sedang waktu itu kami masih musyrik dan mereka ahli kitab. Mereka mengatakan bahwa seorang Nabi yang akan diutus telah dekat masanya, kami akan mengikutinya. Bersama-sama nabi itu kami akan membinasakan kamu seperti Allah membinasakan kaum 'Ad dan Iram. Tetapi setelah Rasulullah saw. diutus, kami mengikutinya, sedang orangorang Yahudi itu mengingkarinya."

Dari kisah ini dapat dipahami, bahwa mereka sebenarnya dengki kepada orang-orang Islam, kedengkian itu timbul setelah Allah mengutus Nabi Muhammad saw., dari kalangan orang-orang Arab, tidak dari kalangan mereka. Itulah sebabnya merek terjerumus di lembah keingkaran dan kekafiran. Maka Allah memberi ketetapan-Nya, bahwa mereka akan terusir dan jauh dari rahmatNya, karena keingkaran mereka pada kebenaran, setelah kebenaran yang diharapkan itu tampak di hadapan mereka (Kemenag, 2010: 150).

Sejarah Bani Israil yang berjalan di lembah kekufuran dan dalam kutukan Allah sudah berjalan begitu lama. Perilaku mereka yang buruk terhadap nabi-nabi mereka dan tidak saling melarang tindakan mungkar dan keji yang mereka perbuat, mengakibatkan mereka dikutuk dan dijauhkan dari rahmat Allah. Mereka mendapat laknat dan dijauhkan dari rahmat Allah di dunia ini, dengan tidak tembusnya sinar-sinar cahaya dan petunjuk itu ke dalam hati mereka. Jika sampai ajal mereka belum bertaubat, maka laknat itu membawa mereka ke dalam neraka dengan siksaan yang pedih.

\section{c. Orang Kafir}

Menurut bahasa kafir artinya menolak atau mengingkari sesuatu. Sehingga orang-orang kafir adalah orang-orang yang menolak dan mengingkari sesuatu. Menurut teologis sebutan kafir dinyatakan oleh suatu agama kepada orang lain yang menolak atau tidak mempercayai seruan pembawa agama tersebut. Menurut 


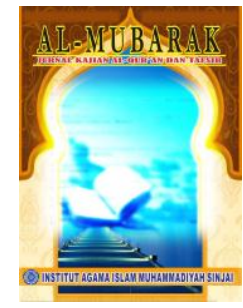

\section{Al-MUBARAK}

Jurmall Kajian Al-Quran \& Tafsir

Volume 4, No. 2, 2019

P-ISSN: 2548-7248

E-ISSN: 2715-5692

Homepage : http://journal.iaimsinjai.ac.id/indeks.php/al-mubarak

Teologi Islam, orang kafir adalah setiap orang yang mengingkari atau tidak percaya kepada kerasulan Nabi Muhammad saw. atau dengan kata lain tidak percaya bahwa agama yang diajarkan oleh Rasulullah saw. berasal dari Allah (Ismail Maulana Syarif, 1996: 193-194).

Allah telah mengancam orang-orang kafir dengan laknat dan siksaan yang keras di akhirat kelak. Sebagaimana firman Allah:

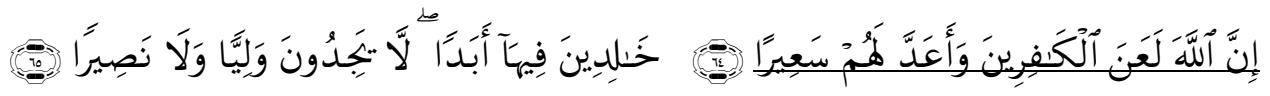

Terjemahnya:

"Sungguh, Allah melaknat orang-orang kafir dan menyediakan bagi mereka api yang menyala-nyala (neraka), mereka kekal di dalamnya selamalamanya; mereka tidak akan mendapatkan pelindung dan penolong" (Depag RI, 2008: 42).

Allah mengusir setiap orang kafir dari rahmat-Nya baik di dunia maupun diakhirat kelak, bagi mereka telah disediakan neraka yang menyala dan bergemuruh di akhirat kelak (Mutawalli Sya'rawi, 2004: 57). Yang dijelaskan dalam firman-Nya:

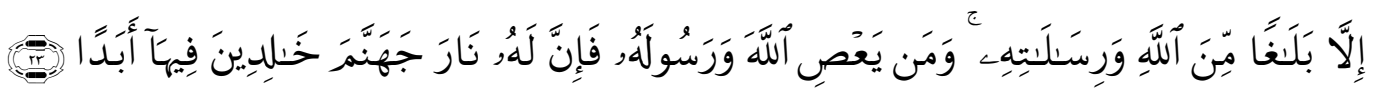

Terjemahnya:

"(Aku hanya) menyampaikan (peringatan) dari Allah dan risalah-Nya. Dan barangsiapa mendurhakai Allah dan Rasul-Nya maka sesungguhnya dia akan mendapat (azab) neraka Jahannam, mereka kekal didalamnya selamalamanya" (Depag RI, 2008: 573).

Menurut Sayyid Quthb (w. 1386 H) dalam tafsirnya mengatakan, sesungguhnya Allah mengusir orang-orang kafir dari rahmat-Nya. Dan, Dia mempersiapkan bagi mereka neraka yang menyala dan panas. Jadi, neraka itu telah siap dan selalu hadir mengazab mereka yang kafir. Mereka akan kekal di dalamnya dalam waktu yang lama, yang tidak diketahui akhirnya melainkan oleh Allah dan tidak ada akhir baginya melainkan hanya dalam ilmu Allah sesuai dengan kehendak-Nya. Mereka sama sekali tidak memiliki penolong, diharamkan bagi mereka mendapat bantuan. Sehingga, tidak ada peluang lolos sama sekali dari api neraka itu, meskipun dengan bantuan dari para wali dan penolong mereka (Sayyid Quthb, 1992: 293). 


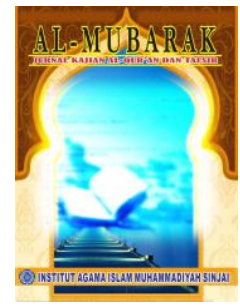

\section{Al-MUBARAK}

Jurmall Kajian Al-Quran \& Tafsir

Volume 4, No. 2, 2019

P-ISSN: 2548-7248

E-ISSN: 2715-5692

Homepage : http://journal.iaimsinjai.ac.id/indeks.php/al-mubarak

Kemudian Allah akan melaknat dan menjauhkan orang-orang kafir dari kebaikan dan rahmat-Nya. Allah juga menyediakan bagi mereka neraka sa'ir (Kemenag, 2010: 45). Yang dimaksud dengan laknat Allah pada ayat ini (QS. AlAhzâb/33:64) adalah kutukan pada hari kiamat yang bersamaan dengan siksa neraka (M. Quraish Shihab, 2009: 543).

Orang-orang yang mengingkari adanya Allah dan syari'at-Nya serta mengingkari para utusan-Nya dan hari kiamat, atau mereka hanya sibuk mengejar kenikmatan duniawi, akan mengakibatkan manusia bersikap egois dan berbuat sekehendak hati, demi memuaskan nafsunya (Afif Abdullah Fattah Thabbarah, 1980: 72). Firman Allah:

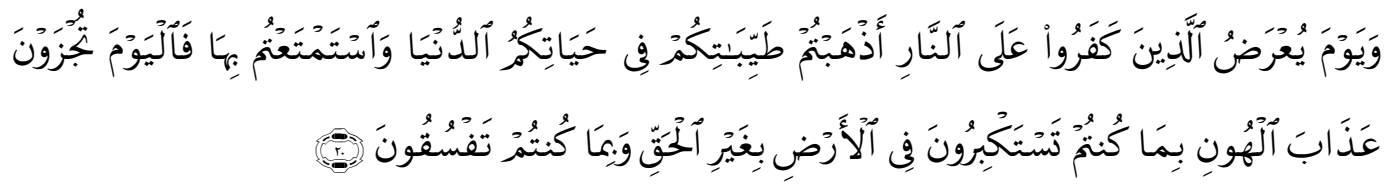

Terjemahnya:

"Dan (ingatlah) pada hari (ketika) orang-orang kafir dihadapkan ke neraka (seraya dikatakan kepada mereka): "Kamu telah menghabiskan (rezki) yang baik untuk kehidupan duniawimu, dan telah kamu telah bersenang-senang (menikmati)nya; maka pada hari ini kamu dibalas dengan azab yang menghinakan, karena kamu sombong di bumi tanpa mengindahkan kebenaran, dan karena kamu berbuat durhaka (tidak taat kepada Allah)" (Depag, 2008: 504).

Jika menyaksikan ada banyak orang kafir yang panjang umur, berlama-lama hidup dalam kekafiran, berpesta pora dengan berbagai kenikmatan harta benda dan kekayaan yang dimilikinya, atau bermabuk-mabuk dalam kesenangan duniawi, tidaklah harus menjadi suatu keanehan, dan tidaklah perlu menjadikan iri dalam hati terhadap mereka. Sebagaimana firman Allah:

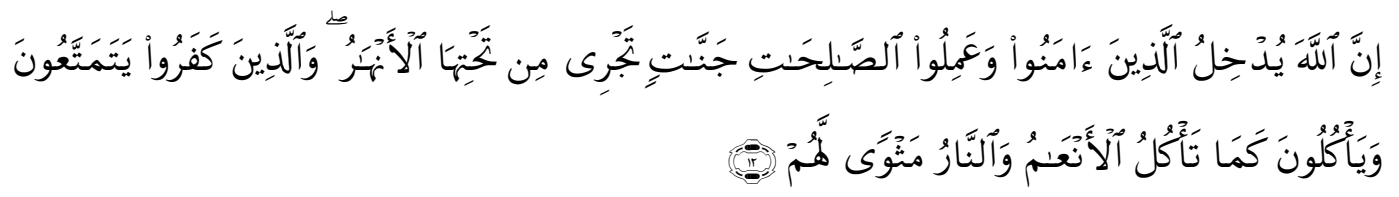

Terjemahnya:

"Sungguh, Allah akan memasukkan orang-orang yang beriman dan mengerjakan kebajikan ke dalam surga yang mengalir di bawahnya sungaisungai. Dan orang-orang yang kafir menikmati kesenangan (dunia) dan mereka makan seperti hewan makan. dan (kelak) nerakalah tempat tinggal bagi mereka" (Depag, 2008: 508). 


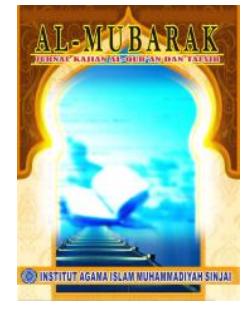

Al-MUBARAK

Jurmall Kajian Al-Quran \& Tafsir

Volume 4, No. 2, 2019

P-ISSN: 2548-7248

E-ISSN: 2715-5692

Homepage : http://journal.iaimsinjai.ac.id/indeks.php/al-mubarak

Inilah sedikit dari laknat Allah di dunia untuk orang yang kafir, perbuatan baik apapun yang dikerjakan oleh orang kafir di dunia tidaklah berbuah pahala, semuanya akan hilang sia-sia. Lantaran sebagaimana janji Allah, bahwa kaum yang kafir itu sengaja diperpanjang atau ditambah umurnya, supaya mereka dapat berpikir atau menyadari kesalahannya selama ini, lantas bertobat memohon ampun, sebelum datang laknat Allah yang berupa azab dan siksa kelak di akhirat.

\section{d. Pemimpin yang Menyesatkan}

Manusia sebagai makhluk sosial, tidak bisa hidup secara sendiri-sendiri melainkan memerlukan hubungan dan bantuan sesama manusia lainnya. Dalam pergaulan hidup antara sesama manusia diperlukan figur seorang pemimpin yang mengatur tata kehidupan dalam masyarakat agar tercipta ketentraman dan ketertiban sebagaimana yang dikehendaki dalam ajaran Islam. Dan terwujudnya ketertiban dan ketentraman masyarakat banyak dipengaruhi oleh faktor kepemimpinan para pemimpin masyarakat atau penguasa Negara. Namun sebaliknya jika ada pemimpin atau penguasa dzalim, curang, dan menyesatkan manusia dari jalan Allah, membuat kekacauan dan kerusakan di muka bumi berarti telah berkhianat atas kepercayaan yang telah diberikan oleh rakyat (H.A.Z. Salim Marie, 1991: 108).

Menzhalimi rakyat, bisa berbentuk penindasan dalam arti luas, atau mengambil hak mereka dengan cara yang tidak benar. Menghukum orang yang benar dan membebaskan orang yang salah, termasuk perbuatan zhalim. Di dalam al-Qur`an Allah memperingatan mereka dengan laknat di dunia dan siksaan yang pedih kelak di akhirat. Sebagaimana firman Allah:

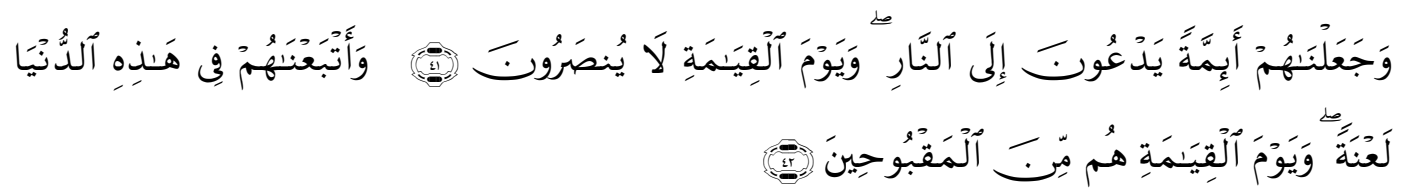

Terjemahnya:

"Dan Kami jadikan mereka para pemimpin yang mengajak (manusia) ke neraka dan pada hari kiamat mereka tidak akan ditolong. Dan Kami susulkan laknat kepada mereka di dunia ini; sedangkan pada hari kiamat mereka termasuk orang-orang yang dijauhkan (dari rahmat Allah)" (Depag RI, 2008: 310). 


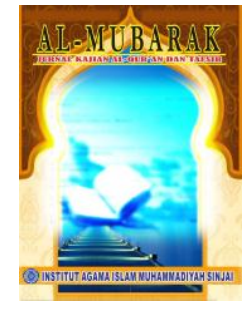

\section{Al-MUBARAK}

Jurnall Kajian Al-Quran \& Tafsir

Volume 4, No. 2, 2019

P-ISSN: 2548-7248

E-ISSN: 2715-5692

Homepage : http://journal.iaimsinjai.ac.id/indeks.php/al-mubarak

Kata aimmah atau pemimpin kata majemuk dari imam/pemimpin yaitu orang yang dijadikan panutan. Imam merupakan teladan bagi makmum dalam kebaikan dan manhaj yang benar. Allah memperingatan kepada pemimpin yang memberi teladan yang buruk dengan ancaman dosa yang amat buruk, seperti dalam firmanNya:

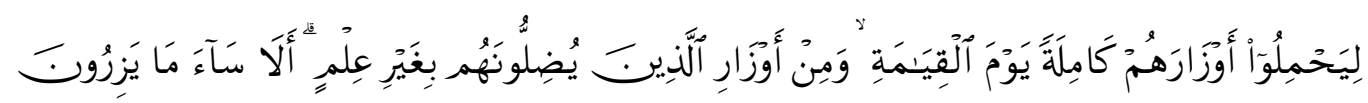

Terjemahnya:

"(Ucapan mereka) menyebabkan mereka pada hari kiamat memikul dosadosanya sendiri secara sempurna, dan sebagian dosa-dosa orang yang mereka sesatkan yang tidak mengetahui sedikit pun (bahwa mereka disesatkan). Ingatlah, alangkah buruknya (dosa) yang mereka pikul itu" (Depag RI, 2008: 269).

Fir'aun dan pembesar-pembesarnya merupakan teladan dalam hal yang buruk, dan kesesatan serta kebengisan. Di akhirat kelak, mereka pun akan menjadi pemimpin dan penguasa tapi di neraka. Fir'aun dan pengikutnya akan menerima laknat abadi selama dunia masih ada. Terlaknat dan jauh dari rahmat Allah bukan merupakan ganjaran dari apa yang mereka perbuat. Ini merupakan bonus atau pengantar bagi azab yang sesungguhnya di akhirat kelak dan abadi (Mutawalli Sya'rawi, 2004: 297).

Di samping peringatan-peringatan keras dan laknat terhadap penguasa yang menyesatkan lagi zalim terhadap rakyatnya di dunia maupun di akhirat kelak dari Allah, Rasulullah saw. pun bersabda tentang penguasa yang zalim terhadap rakyatnya ( Ahmad ibn Hanbal, t.th.: 275). :

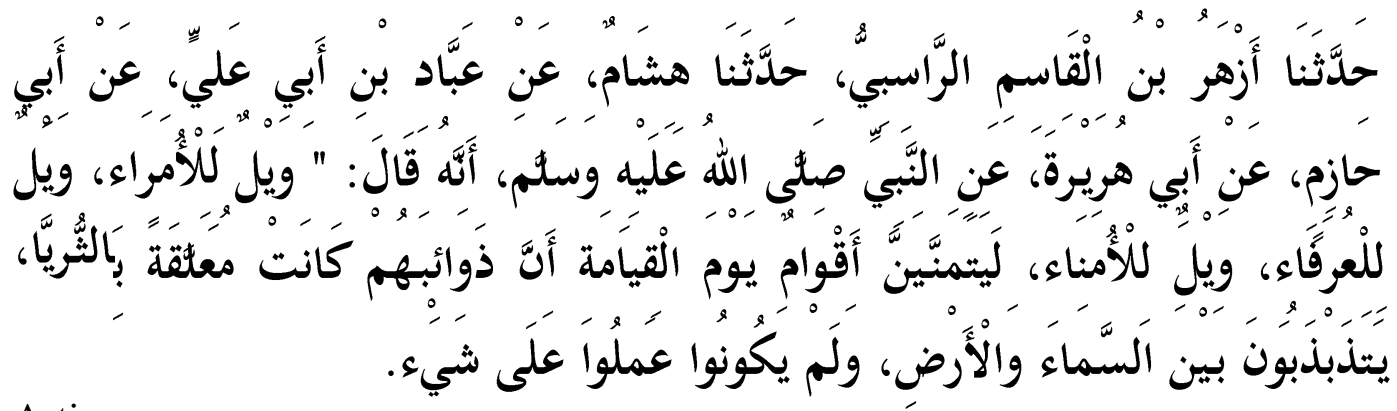

Artinya:

"Diriwayatkan dari Azhar bin al-Qasim al-Rasibi dari Hisyam dari 'Abad bin Abi 'Ali dari Abi Hazim dari Abi Hurairah dari Nabi saw., sesungguhnya Beliau bersabda: "Celakalah para penguasa, celakalah para 


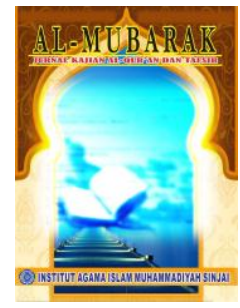

Al-MUBARAK

Jurmall Kajian Al-Quran \& Tafsir

Volume 4, No. 2, 2019

P-ISSN: 2548-7248

E-ISSN: 2715-5692

Homepage : http://journal.iaimsinjai.ac.id/indeks.php/al-mubarak

pemangku urusan rakyat, dan celakalah orang-orang yang dipercayai mengurus kepentingan umum, sungguh banyak orang pada hari kiamat nanti berangan-angankecurangan-kecurangan mereka tergantung di atas bintang Tsurayya. Mereka akan disiksa karena mereka dahulu tidak mau melakukan sesuatu yang jadi amanatnya".

Dengan demikian menjadi jelas tentang besarnya dosa bagi para penguasa yang berbuat zhalim dan yang menyesatkan rakyatnya melalui dalil-dalil AlQur`an dan Hadis. Mereka pantas menerima siksaan yang berlipat ganda, yakni siksaan terhadap kesesatan sendiri dan siksaan karena menyesatkan orang lain. Dengan kata lain, laknat, kutukan dan kejauhan dari rahmat Allah terus menerus mengikuti mereka dari saat ke saat.

\section{e. Orang yang Berdusta}

Para Ulama telah sepakat bahwa dusta atau berbohong ialah memberikan, menyampaikan informasi yang tidak sesuai, tidak sama dengan yang sebenarnya. Dalam hal ini, berdusta ada tiga macam, yakni berdusta dengan perkataan, tulisan dan berdusta dalam hati (H.A.Z. Marie, 1991: 55), sebagaimana firman Allah yang berbunyi:

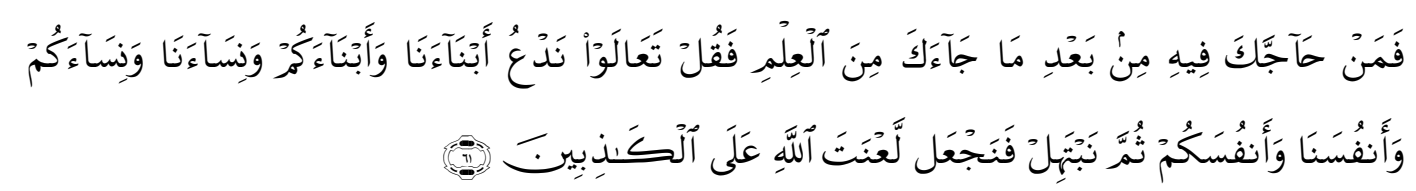

Terjemahnya:

"Siapa yang membantahmu dalam hal ini setelah engkau memperoleh ilmu, katakanlah (Muhammad): "Marilah kita panggil anak-anak kami dan anakanak kamu, isteri-isteri kami dan isteri-isterimu, kami sendiri dan kamu juga, kemudian marilah kita bermubahalah agar laknat Allah ditimpakan kepada orang-orang yang dusta" (Depag RI, 2008: 57).

Dalam ayat ini Allah memerintahkan kepada Nabi Muhammad bila masih ada orang yang membantah kebenaran berita tentang kejadian Isa as., sesudah mendapat penjelasan hendaklah mereka diajak ber-mubâhalah untuk membuktikan siapa yang benar dan berdoa agar Allah menjatuhkan laknat-Nya kepada orang yang berdusta. Namun Demikian, mereka (Nasrani Najran) menolak ajakan Nabi Muhammad, mereka takut akibatnya dan tidak mau melakukan mubâhalah (Sayyid Quthb, 1992: 118). 


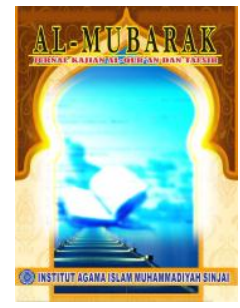

\section{Al-MUBARAK}

Jurnall Kajian Al-Quran \& Tafsir

Volume 4, No. 2, 2019

P-ISSN: 2548-7248

E-ISSN: 2715-5692

Homepage : http://journal.iaimsinjai.ac.id/indeks.php/al-mubarak

Berdusta bukan saja merugikan orang lain tetapi juga merugikan diri sendiri, karena ia akan kehilangan harga diri dan orang lain tidak lagi menaruh kepercayaan terhadapnya, ini sebagian kecil dari bentuk laknat di dunia. Rasulullah bersabda (Muslim, t.th.: 2013):

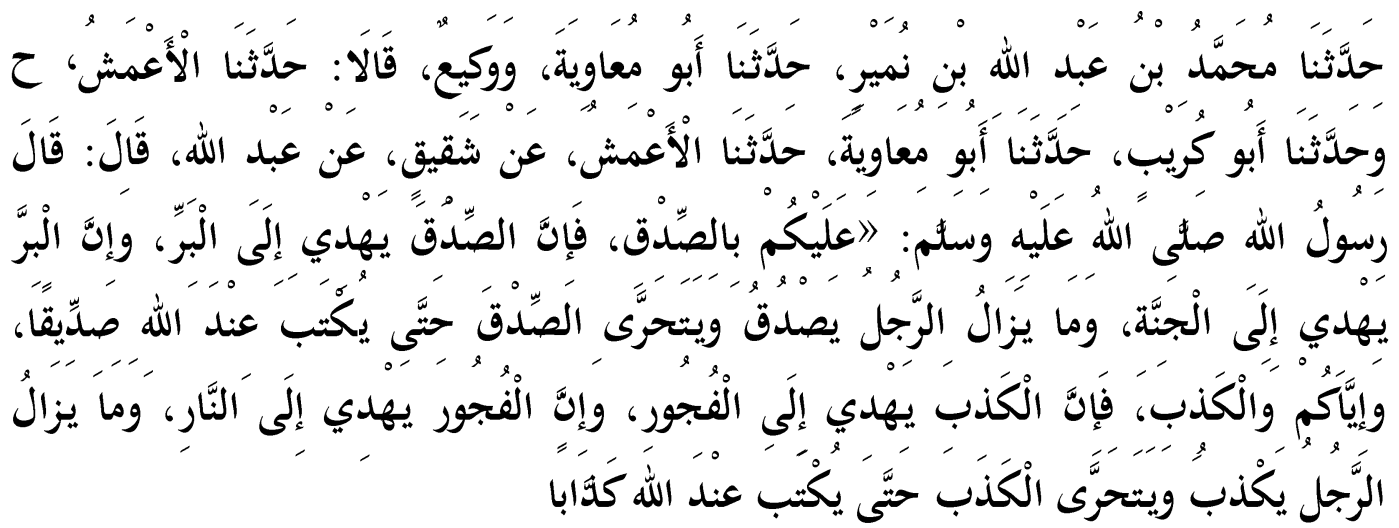

Artinya:

"Diriwayatkan dari Muhammad bin Abdillah bin Numair dari Abu Mu’awiyah dan waki berkata: Dari Al A`masy dari Abu Kuraib dari Abu Mu`awiyah dari Al-A`masy dari Syaqiq dari Abdillah, berkata Rasulullah saw: "Biasakanlah berkata benar, karena benar itu menuntun kepada kebaikan dan kebaikan itu akan menuntun ke syurga, dan orang itu selalu berkata benar, dan menjaga supaya tetap benar, sehingga dicatat disisi Allah sebagai seorang siddiq (yang amat benar). Dan berhati-hatilah dari dusta, karena dusta menuntun kedalam neraka, dan selalu seorang hamba berlaku dusta sehingga tercatat disisi Allah sebagai pendusta".

Dusta merupakan salah satu dosa yang diancam oleh Allah dengan laknat dan siksaan yang pedih di akhirat kelak. Allah berfirman:

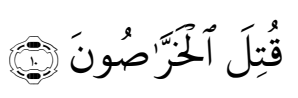

Terjemahnya:

"Terkutuklah orang-orang yang banyak berdusta" (Depag RI, 2008: 521).

Ayat ini menjelaskan bahwa Allah mengutuk orang-orang yang berdusta atau yang berkata tanpa dasar yang jelas berkaitan dengan hal-hal yang memerlukan keterangan yang pasti (M. Quraish Shihab, 2009: 30).

\section{f. Orang Munafik}

Kaum munafik adalah kaum yang ingkar dan berpura-pura atau penuh dengan kepura-puraan, mereka selalu mengucapkan apa yang tidak sesuai dengan hatinya, dan bertindak berbeda dengan ucapannya. Oleh sebab itu, keberadaan orang munafik sangatlah berbahaya bagi manusia lainnya. Lantaran mereka 


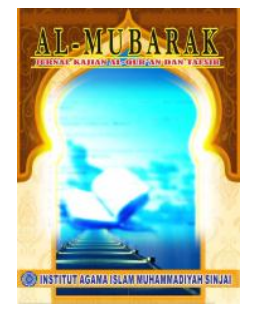

\section{Al-MUBARAK}

Jurnall Kajian Al-Quran \& Tafsir

Volume 4, No. 2, 2019

P-ISSN: 2548-7248

E-ISSN: 2715-5692

Homepage : http://journal.iaimsinjai.ac.id/indeks.php/al-mubarak

adalah jenis manusia pendusta, pembohong, penipu dan penghianat. Mereka akan tega mencelakakan teman sendiri dengan menghalalkan segala macam cara untuk dapat memenuhi tujuan dan keinginannya. Allah tidak menyukai orang-orang munafik, sehingga mereka diancam laknat Allah berupa neraka jahannam dengan berbagai azab dan siksa yang sangat pedih dan menghinakan. Firman Allah:

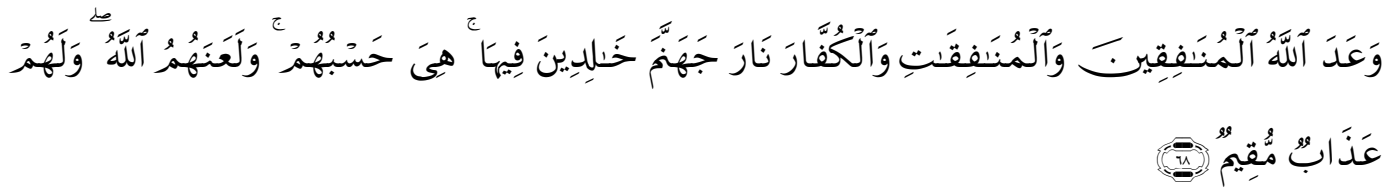

Terjemahnya:

"Allah menjanjikan (mengancam) orang-orang munafik laki-laki dan perempuan dan orang-orang kafir dengan neraka Jahannam. Mereka kekal di dalamnya. Cukuplah (neraka) itu bagi mereka. Allah melaknat mereka; dan mereka mendapat azab yang kekal" (Depag RI, 2008: 197).

Kata الوعد yang berarti janji, terkadang dipergunakan untuk hal yang baik dan juga yang buruk. Oleh karena itu, ketika seseorang yang mendengar kata ini dipergunakan, maka dia berharap akan mendapat kebaikan. Namun jika sebaliknya, maka keburukan yang menimpanya akan terasa lebih menyakitkan. Dalam ayat ini Allah mengedepankan munafikin dari pada orang kafir. Hal ini sejalan dengan firman Allah:

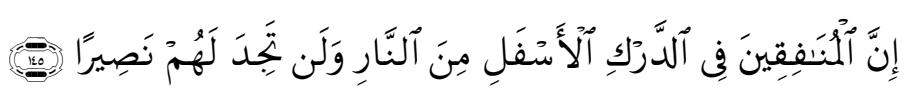

Terjemahnya:

"Sungguh, orang-orang munafik itu (ditempatkan) pada tingkatan yang paling bawah dari neraka. Dan kamu tidak akan mendapat seorang penolong pun bagi mereka" (Depag RI, 2008: 101).

Firman Allah selanjutnya "cukuplah neraka itu bagi mereka", menunjukkan ولعنهم الهه : bahwa neraka cukup atas orang munafik. Selanjutnya Allah mengatakan dan Allah melaknati mereka, yaitu dengan mengusir mereka dari rahmat-Nya, kemudian Allah tidak menerima taubat mereka. Sebab, tempat taubat adalah di dunia bukan di akhirat (Mutawalli Sya'rawi, 2004: 286-288).

Menurut Sayyid Quthb (w. 1386 H) di dalam tafsirnya mengatakan, bahwa mereka (orang munafik) keluar dari iman dan menyimpang dari jalan yang benar. Allah mengancam orang-orang munafik dengan tempat kembali yang sangat buruk (neraka jahannam) sebagaimana yang diancamkan kepada orang-orang kafir dan mereka terjauhkan dari rahmat Allah (Allah melaknat mereka). Hal ini 


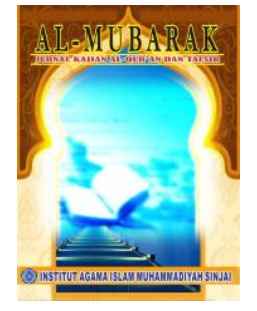

\section{Al-MUBARAK}

Jurmall Kajian Al-Quran \& Tafsir

Volume 4, No. 2, 2019

P-ISSN: 2548-7248

E-ISSN: 2715-5692

Homepage : http://journal.iaimsinjai.ac.id/indeks.php/al-mubarak

senada dengan apa yang disampaikan oleh Quraish Shihab di dalam Tafsîr Mishbah (M. Quraish Shihab, 2009: 150).

Di antara sifat-sifat orang-orang munafik yang disebutkan dalam al-Qur`an adalah:

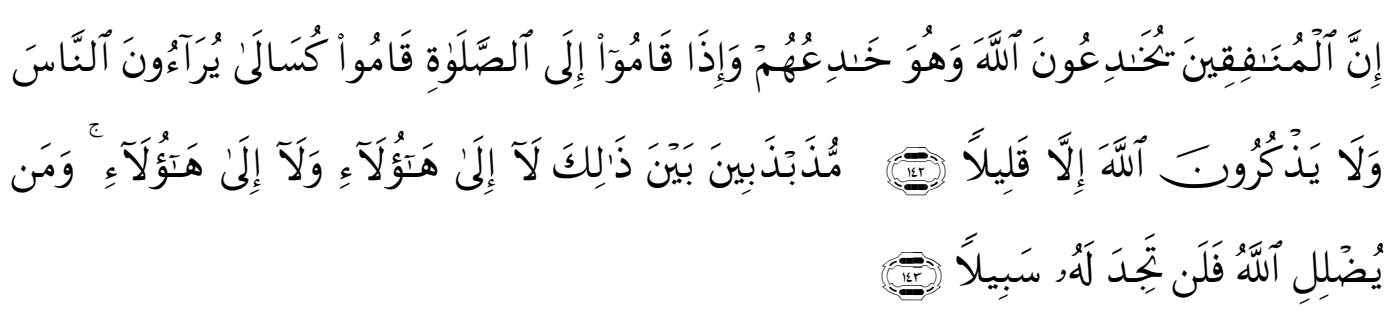

Terjemahnya:

"Sesungguhnya orang munafik itu hendak menipu Allah, tetapi Allah-lah yang menipu mereka. Apabila mereka berdiri untuk shalat mereka lakukan dengan malas. Mereka bermaksud riya (ingin dipuji) di hadapan manusia. Dan mereka tidak mengingat Allah kecuali sedikit sekali. Mereka dalam keadaan ragu antara yang demikian (iman atau kafir) idak termasuk kepada golongan ini (orang beriman) dan tidak (pula) kepada golongan itu (orang kafir). Barang siapa dibiarkan sesat oleh Allah, maka kamu tidak akan mendapat jalan (untuk memberi petunjuk) baginya" (Depag RI, 2008: 101).

\section{Simpulan}

Setelah mengkaji wawasan al-Qur`an tentang laknat dapat disimpulkan beberapa hal berikut ini, yakni: Pertama, kata la'ana dalam berbagai bentuk derivasinya terungkap di dalam al-Qur`an sebanyak 40 ayat. Kedua, laknat adalah dijauhkan dan diusir dari rahmat-Nya disertai dengan murka Allah di dunia dan hukuman neraka di akhirat kelak. Ketiga, di antara objek laknat dalam al-Qur`an adalah Iblis, Bani Israil, orang kafir, orang munafik, pendusta, serta penguasa yang lalim.

\section{Daftar Pustaka}

Abd al-Baqi', Muhammad Fuad. (2007). Al-Mu'jam al-Mufahras li Alfâzh AlQur`an. Cairo: Dar al-Hadis.

Abdullah bin Muhammad bin 'Ali al-Anshari, Abu Ismail. (1998). Dzam alKalâm wa Ahlihi. Madinah al-Munawarah: Maktabah al-'Ulum wa alHikam.

Ahmad bin Muhammad bi Hanbal, Abu Abdullah. (2001). Musnad al-Iman Ahmad bin Hanbal. Beirut: Muassasah al-Risalah. 


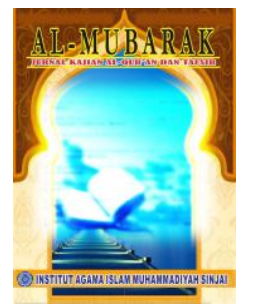

\section{Al-MUBARAK}

Jurnal Kajian Al-Quran \& Tafsir

Volume 4, No. 2, 2019

P-ISSN: 2548-7248

E-ISSN: 2715-5692

Homepage : http://journal.iaimsinjai.ac.id/indeks.php/al-mubarak

Amir, Ismail. (2011). Laknat dalam Pandangan Al-Qur an (Analisis Ayat-Ayat

Laknat Dalam Tafsir Al-Maraghi). Jakarta: UIN Syarif Hidayatullah.

Al-Bukhari, Muhammad bin Ismail Abu Abdullah. (1422 H). Shahîh Al-Bukhâri.

Kairo: Dar Thaûq Al-Najah.

Ad-Dahduh, Salman Nashif. (2008). 100 yang terlaknat, diterjemahkan oleh Amir

Ghozali. Solo: WIP.

Departemen Agama RI. (2008). Al-Qur`an dan Terjemahnya. Depok: Cahaya Qur`an.

Fattah Thabbarah, Afif Abdullah. (1980). Dosa-dosa Menurut al-Qur`an diterjemahkan oleh Bahrun Abu Bakar. Bandung: Gema Risalah Press.

Ibnu Manzur. (t.th.). Lisan al-Arab. Beirut: Dar Sadir.

Ibrahim, Majdi Assayid. (1995). Wanita dan Laki-laki yang Dilaknat. Jakarta: Gema Insani Press.

Kementerian Agama RI. (2010). Al-Qur`an dan Tafsirnya. Jakarta: Kementerian Agama RI, 2010.

Al-Maraghi, Ahmad Mustafa. (1992). Tafsîr Al-Maraghî. Kairo: Dar al-Kutub.

Marie, H.A.Z. Salim. (1991). 80 Dosa Besar. Bandung: Husaini.

Muhaimin As'ad, Abdul. (t.th.). 99 Dosa Besar: Larangan Allah dan 35 Kitabul Fadhilah. Surabaya: Bintang Terang 99.

An-Naisabury, Muslim bin Hajjaj Abu al-Hasan al-Qusyairi. (t.th.). Shahih Muslim. Beirut: Daar Ihya at-Turats.

Quthb, Sayyid. (1992). Fi Zhilalil Qur`an diterjemahkan oleh As'ad Yasin, A. Aziz S, dan Muchotob Hamzah. Jakarta: Gema Insani Press.

Ash-Shabuny, Muhammad Ali. (2000). Cahaya Al-Qur`an diterjemahkan oleh Kathur Suhardi. Jakarta: Pustaka Al-Kautsar.

Shihab, M. Quraish. (2009). Tafsîr Al-Mishbah: Pesan, Kesan, dan Keserasian AlQur`an. Jakarta: Lentera Hati.

Asy-Sya'rawi, Muhammad Mutawalli. (2004). Tafsir Sya'rawi diterjemahkan oleh Tim Terjemah Safir al-Azhar. Jakarta: Duta Azhar.

Syarif, Ismail Maulana. (1996). Azab dan Siksa Menurut al-Qur`an. Jakarta: Fikahati Aneska. 